University of Nebraska - Lincoln

DigitalCommons@University of Nebraska - Lincoln

Agronomy \& Horticulture -- Faculty Publications

Agronomy and Horticulture Department

$1-1938$

Root Distribution of Trees in Relation to Soil Profile

J. E. Weaver

University of Nebraska-Lincoln

Follow this and additional works at: https://digitalcommons.unl.edu/agronomyfacpub

Part of the Plant Sciences Commons

Weaver, J. E., "Root Distribution of Trees in Relation to Soil Profile" (1938). Agronomy \& Horticulture -Faculty Publications. 455.

https://digitalcommons.unl.edu/agronomyfacpub/455

This Article is brought to you for free and open access by the Agronomy and Horticulture Department at DigitalCommons@University of Nebraska - Lincoln. It has been accepted for inclusion in Agronomy \& Horticulture -Faculty Publications by an authorized administrator of DigitalCommons@University of Nebraska - Lincoln. 


\section{Root Distribution of Trees in Relation to Soil Profile ${ }^{1}$}

One of the pronounced trends in American forestry during the past decade has been the development of a widespread interest in soils. As a consequence to the soil as a part of the environmental complex has been attributed much greater importance than formerly in forest production. In fact, the individual horizons of the soil profile are receiving attention each as a more or less distinct habitat of that highly organized body designated as soil. Just as soil scientists, until recent years, have given inadequate attention to the factor of vegetation in the constitution and development of soils, so too little attention has been paid to the effect of soil profile on root development. This investigation is, in fact, among the few that give adequate consideration to the diverse factors of soil profile and their effects upon root growth. The modern concept of the dominant role of climate and vegetation in soil formation and that of the effects of soil horizons on root activities furnishes a broad foundation for further ecological research. For example, when it is determined that the vertical distribution of the roots of forest trees in the substratum is closely related to certain soil horizons, a better understanding of methods of soil sampling and a clearer interpretation of soil data in terms of tree behavior are to be had.

A review is given of what has been learned concerning those soil factors considered most important in the determination of the behavior of roots from the early observations of Goff in 1887 to the present. One is impressed by

${ }^{1}$ Lutz, H. J., J. B. Ely, and S. Little. 1937. The influence of soil profile horizons on root distribution of white pine (Pimus strobus L.). Yale Univ': School of Forestry, Bull. 44: 1-57. 20 fig. 
the relatively large number of studies on roots of woody plants that have been made since the publication of the classical work of Laitakari " in 1927.

The present investigation of the relation of soil profile horizons to root distribution of white pine was made in the Yale Demonstration and Research Forest near Keene, New Hampshire, during 1934 and 1935. The soils were of the gray-brown podzolic group and the trees were of even-aged, well stocked, pure stands established by natural regeneration and 35 to 45 years old. Of the 23 profiles examined, 17 are described and discussed. Root examinations were made by means of the trench method, the excavations being 12 by 2.5 feet and the depth 5 to 7 feet. A horizontal wall was divided into foot squares and the root ends were charted, symbols being used to designate the various size classes. Both the average number of roots exposed in vertical cross sections 10 feet in length and the average number per square foot of rock-free cross-sectional area were determined.

In most profiles the largest number of roots were found in the $\mathrm{A}$ and $\mathrm{B}$ horizons (i.e., to depths 8 to 24 inches) but the average number of roots per square foot (407) in the thin layer of leafmold was higher than in any other horizon. Root numbers per square foot of cross-sectional area in mineral soil horizons decreased with increasing depth below the surface. Mechanical composition of the soil horizons greatly influenced root distribution. Root development was poor or lacking in soil material containing 90 per cent or more of sand and also in very compact layers. It appeared better where total nitrogen content was highest, but no consistent relation between $\mathrm{pH}$ and root distribution could be established. Concentration of the roots in the upper soil horizons was believed to result from greater content of fine material less than $0.05 \mathrm{~mm}$. diameter; generally better physical conditions, particularly structure and consistency, higher moisture equivalent values, higher content of organic matter and total nitrogen, and higher total exchange capacity and content of exchangeable bases. The productivity of the soil body was closely associated with the $\mathrm{A}$ and $\mathrm{B}$ horizons. Thus the ecological as well as the pedological significance of soil profile horizons seems clear.

This excellent study is accompanied with numerous illuminating figures and a well chosen bibliography.

J. E. Weaver

University of Nebraska

${ }^{2}$ Laitakari, Erkki. 1927. Männyn juuristo. Morfologinen tutkimus. (The root system of pine, Pimus siliestris.) (English summary, pp. 307-380.) Acta Forestalia Fennica $33: 1-380$. 